\title{
DIFFERENCE IN CONSUMPTION BETWEEN URBAN AND RURAL HOUSEHOLDS
}

\author{
Magdalena Cyrek, $\mathrm{PhD}^{1}$, Piotr Cyrek, $\mathrm{PhD}^{1}$
}

Faculty of Economics, University of Rzeszów

\begin{abstract}
Levels of income, consumer expenditure and their structure display significant disproportions between areas of different degrees of urbanisation. These disproportions are reflected both in the objective comparison and subjectively perceived material situation of households. This study contains an assessment of the differences in income and consumption in rural areas and cities of Poland at a national level and in relation to the Subcarpathian Province, as a less developed region. The results of public statistic surveys were supplemented with the results of own research regarding the perception of the situation by the inhabitants of Subcarpathia. The scale of existing socio-economic disproportion in spatial layout and directions of changes in accordance to objective and subjective indicators were identified. The changes in the value of purchases of various types of products, levels of savings and living conditions were addressed. In order to verify the hypothesis of consumption convergence in the city-countryside system, a statistical analysis of national structures was carried out and the differences in change patterns typical for urban and rural households in Subcarpathia were identified. This research allows to conclude that there exist adverse disproportions in rural development and some signs of overcoming them on a national and regional level.
\end{abstract}

Keywords: consumption, well-being, households, city-countryside JEL codes: D10, D31, D60, I30, I31, O15, O18, R12, R20

\section{INTRODUCTION}

In modern times, well-being in rural areas is considered to be a complex phenomenon, which encompasses a desire to balance economic parameters with personal, social and environmental matters (Rivera et al., 2018). One of the primary indicators of the standard and quality of living is the manner of wealth distribution, including the level and structure of consumption. Patterns in this scope are often different in urban and rural areas, which is visible not only in the difference in lifestyles, but also in the level of an inhabitant's well-being.

The goal of this study is the identification of differences existing among the residents of cities and villages in Poland and in the character of consumption. The hypothesis of decreasing spatial inequality and the simultaneous existence of adversity for villagers in the level of well-being will be verified. It is assumed that it is both objective and subjective in nature as well as linked with the perception of the material situation of one's own household. Since it

${ }^{1}$ Corresponding author: Ćwiklińskiej 2, 35-601 Rzeszów, Poland, mcyrek@ur.edu.pl

${ }^{2}$ Corresponding author: Ćwiklińskiej 2,35-601 Rzeszów, Poland, piotrcyr@univ.rzeszow.pl 
is assumed that convergence occurs in relation to the improvement of the level of general well-being, variation in consumption should be highest in the poorest regions. Therefore, special attention is devoted to the material situation of households from the Subcarpathian region which is characterised by one of the lowest GDP per capita in the country.

\section{THEORETICAL BACKGROUND}

Variation in the standard of living, described by the level of income or consumption between urban and rural areas is the subject of intensive research. The analyses are focused on identifying factors determining the incidence of disproportions and changes in the depth of the observed gap. By comparing different countries, Simler and Dudwick (n.d.) refer to a paradigm, according to which the growth level of income initially increases inequality of well-being between the city and the countryside, which is then followed by convergence. However, they point out that there are almost as many examples of countries with observable processes of a living standard convergence as those where divergence is common, even among economies of a similar level of urbanisation or GDP per capita.

In European countries inequality in the city-countryside system are mostly a subject of analyses in less developed countries, where intense processes of structural changes are occurring. Gîdiu and Toader (2011) point out that, in Romania, the differences between the city and the countryside in terms of income, consumption and structure are not only significant but also growing. Similarly as in Poland, the existence of a well-being gap between the city and the countryside are a point of interest for many researchers. For instance, Chmieliński and Chmielewska (2015) reached a conclusion that despite great differences in i.a. the level and structure of income and expenditure, the convergence of the economic situation is still observable. Utzig (2017) concludes that rural and urban households move their consumption patterns towards less sustainable consumption. Similarly, Leśniak-Moczuk (2008) claims that the consumption model of the rural population transforms into a universal model of mass consumption, which is typical for city dwellers.
In the most developed countries, extended research of consumption patterns is also conducted but are focused on individual categories of expenditure and the nature of the consumption structure. Barigozzi et al. (2012) analysed the structure of household expenditure in Italy between 1989-2004 in four categories: nondurable goods, food, durable goods, and insurance premia. The conclusion was drawn that there was no significant difference over time. However, studies of consumption behaviour in Ireland conducted by (Carey et al., 2014) indicate that they are susceptible to modification influenced by general economic development changes. By comparing urban and rural households, the authors point out that the purchase patterns analysed in spatial layout are visibly varied, which is caused by socio-economic characteristics of the client, as well as spatial properties of trade network development and categories of purchased products.

\section{MATERIALS AND METHODS}

The study refers to a variation in consumption when comparing the city and the countryside on a national and regional level. The source of data for national scope are the results of each edition of household budget surveys carried out by GUS between 2006-2016, which were supplemented by public statistic data presented by GUS in the local data bank and Eurostat. The scale of differences in the structure of expenditure on consumer goods and services was analysed in relation to six spending groups categorised as: food (food and non-alcoholic beverages; alcoholic beverages, tobacco and narcotics), clothing and footwear, accommodation (housing, water, electricity, gas and other fuels; furnishing household equipment and routine maintenance of the house), investment in human capital (health; recreation and culture; education), communication (transport; communication), and others (restaurants and hotels; miscellaneous goods and services; pocket-money). The variation in the structure over time and in the spatial layout was measured on the basis of statistical analysis of structures (SAS) based on Kukuła's variation measurement method (Kukuła, 1996).

What was also included was the specificity of the material situation of inhabitants of cities and vil- 
Proceedings of the 2018 International Scientific Conference 'Economic Sciences for Agribusiness and Rural Economy' No 2, Warsaw, 7-8 June 2018, pp. 68-74

lages in relatively poorly developed regions, such as the Subcarpathian Province. In this arrangement, the results of our own research carried out on a group of 611 inhabitants, in the last quarter of 2015 and in the first quarter of 2016, using the method of direct interview, were used.

\section{RESULTS AND DISCUSSION}

The summary of characteristics, determining the level of well-being in urban and rural areas (Fig. 1), indicates an accumulation of numerous socio-economic problems and adverse disproportions in rural develop- ment. Villagers earn less than $3 / 4$ of a city dweller's income, and therefore spend less. Additionally, the level of income is definitely more internally varied in rural areas, which indicates existing social disproportions. Adverse income inequality is accompanied by lower economic activity, a higher unemployment rate and lower employment rates in the countryside. Rural areas are also more vulnerable to poverty and social exclusion.

The changes. which were examined between 2006-2016. do not lead to a definite diagnosis regarding the lowering of the development gap in rural areas in relation to the city. On the one hand. the improve-

Table 1. Disproportions in the level of selected socio-economic indicators between rural and urban areas in Poland between 2006-2016

\begin{tabular}{|c|c|c|c|c|c|c|c|c|c|c|c|}
\hline Specification & 2006 & 2007 & 2008 & 2009 & 2010 & 2011 & 2012 & 2013 & 2014 & 2015 & 2016 \\
\hline \multicolumn{12}{|c|}{ Average monthly available income per capita in households } \\
\hline Rural/urban (\%) & 69.8 & 71.3 & 71.1 & 70.9 & 71.0 & 70.5 & 71.4 & 73.0 & 70.4 & 70.6 & 73.9 \\
\hline \multicolumn{12}{|c|}{ Average monthly per capita expenditures on consumer goods and services in households } \\
\hline Rural/urban (\%) & 72.1 & 71.9 & 72.8 & 72.5 & 72.8 & 72.8 & 73.2 & 73.8 & 73.1 & 73.0 & 74.8 \\
\hline \multicolumn{12}{|c|}{ Activity rate by LFS (\%) } \\
\hline Urban & 68.3 & 68.6 & 69.7 & 70.7 & 71.7 & 72.4 & 73.3 & 74.1 & 75.2 & 75.5 & 76.3 \\
\hline Rural & 70.7 & 69.9 & 70.4 & 71.2 & 71.5 & 71.7 & 72.4 & 72.6 & 73.0 & 72.9 & 73.5 \\
\hline \multicolumn{12}{|c|}{ Unemployment rate by LFS (\%) } \\
\hline Urban & 14.4 & 9.9 & 7.2 & 8.3 & 9.9 & 9.7 & 10.0 & 10.3 & 8.7 & 7.2 & 5.9 \\
\hline Rural & 13.0 & 9.2 & 7.0 & 8.0 & 9.2 & 9.5 & 10.2 & 10.4 & 9.5 & 8.0 & 6.5 \\
\hline \multicolumn{12}{|c|}{ Employment rate by LFS (\%) } \\
\hline Urban & 58.4 & 61.8 & 64.6 & 64.8 & 64.5 & 65.2 & 65.8 & 66.3 & 68.5 & 70.0 & 71.7 \\
\hline Rural & 61.3 & 63.3 & 65.3 & 65.4 & 64.8 & 64.7 & 64.8 & 64.8 & 66.0 & 67.0 & 68.6 \\
\hline \multicolumn{12}{|c|}{ People at risk of poverty or social exclusion (\%) } \\
\hline Urban & 32.3 & 28.0 & 23.5 & 21.1 & 21.1 & 21.2 & 20.4 & 19.8 & 17.8 & 16.7 & 16.2 \\
\hline Rural & 45.1 & 39.0 & 36.1 & 33.6 & 33.9 & 32.7 & 33.2 & 32.5 & 31.2 & 30.0 & 27.9 \\
\hline \multicolumn{12}{|c|}{ Difference in income measured by Gini coefficient } \\
\hline Urban & 0.329 & 0.325 & 0.315 & 0.312 & 0.323 & 0.317 & 0.317 & 0.312 & 0.306 & 0.303 & 0.288 \\
\hline Rural & 0.331 & 0.341 & 0.343 & 0.338 & 0.339 & 0.337 & 0.343 & 0.352 & 0.329 & 0.323 & 0.305 \\
\hline
\end{tabular}

Source: own research based on GUS (2006-2017), Local Data Bank of Statistics Poland (GUS), Eurostat database: People at risk of poverty or social exclusion by degree of urbanisation [ilc_peps13]. 
ment of the situation in the countryside may indicate a growth in the relation of the level of income and expenses. a decrease in the risk of the poverty rate and an increase in economic activity. the employment rate and reduction of unemployment. On the other hand. inequalities regarding income and consumption in relation to cities are significant and the relative level of labour market indicators in the countryside in comparison to cities since the period 2010-2012 has become less favourable for rural residents.

The structure of consumption expenditure of Polish households (Table 2) mostly involves expenses on basic necessities. namely food and accommodation. However, while in 2016. the cost of food was the highest value in rural household budgets. in cities. they were on the same level as accommodation costs. The countryside involved noticeably higher costs of transportation. which stem from the need to commute to the workplace or to infrastructures by countryside inhabitants. In cites. expenses regarded as investment in human capital were more crucial. Also. the share of other expenses was higher and included goods satisfying higher needs. such as mass consumption and needs appearing in the case of financial surplus. In conclusion. the differences in the structure of expenditure reflect the different levels of well-being in the city and countryside. In rural households. the expense proportions are typical of poorer societies. which devote a larger share of income to sustaining ongoing basic needs.

Between 2006-2016 two notable tendencies in the changes of consumption expenditure could be observed. Firstly, the share of food costs decreased both in the city and the countryside. This tendency was relatively stable in rural areas. whereas. in cities. it was prone to cyclical fluctuations. Secondly,

Table 2. The structure of expenditure on consumer goods and services of urban and rural households in Poland between 2006-2016

\begin{tabular}{|c|c|c|c|c|c|c|c|c|c|c|c|}
\hline Specification & 2006 & 2007 & 2008 & 2009 & 2010 & 2011 & 2012 & 2013 & 2014 & 2015 & 2016 \\
\hline \multicolumn{12}{|l|}{ Urban $(\%)$} \\
\hline Food & 28.9 & 28.4 & 27.4 & 27.1 & 27.0 & 27.1 & 27.4 & 27.1 & 26.6 & 26.2 & 26.3 \\
\hline Clothing and footwear & 5.7 & 6.0 & 5.8 & 5.6 & 5.7 & 5.5 & 5.2 & 5.3 & 5.6 & 5.7 & 5.8 \\
\hline Accommodation & 26.5 & 25.5 & 25.7 & 26.5 & 26.8 & 26.9 & 26.8 & 27.0 & 26.6 & 26.8 & 26.3 \\
\hline Communication & 14.3 & 14.8 & 15.4 & 14.8 & 14.3 & 14.2 & 14.0 & 15.1 & 14.4 & 14.0 & 14.0 \\
\hline $\begin{array}{l}\text { Investment in human } \\
\text { capital }\end{array}$ & 15.4 & 15.8 & 16.0 & 16.0 & 16.1 & 16.1 & 16.2 & 14.2 & 14.1 & 14.5 & 14.6 \\
\hline Other & 9.2 & 9.4 & 9.6 & 10.0 & 10.2 & 10.2 & 10.5 & 11.2 & 12.7 & 12.8 & 13.0 \\
\hline \multicolumn{12}{|l|}{ Rural (\%) } \\
\hline Food & 36.2 & 35.6 & 33.9 & 33.5 & 33.0 & 33.1 & 32.6 & 32.0 & 31.5 & 31.1 & 31.2 \\
\hline Clothing and footwear & 5.4 & 5.8 & 5.5 & 5.2 & 5.2 & 5.0 & 5.0 & 5.2 & 5.5 & 5.7 & 6.0 \\
\hline Accommodation & 24.8 & 23.8 & 24.9 & 25.5 & 26.0 & 26.2 & 25.2 & 25.6 & 25.0 & 25.1 & 24.7 \\
\hline Communication & 15.0 & 15.3 & 15.6 & 15.2 & 15.3 & 14.7 & 15.3 & 16.1 & 15.9 & 15.4 & 14.8 \\
\hline $\begin{array}{l}\text { Investment in human } \\
\text { capital }\end{array}$ & 11.2 & 11.6 & 11.8 & 12.3 & 12.0 & 12.3 & 12.5 & 11.5 & 11.3 & 11.7 & 12.0 \\
\hline Other & 7.4 & 7.8 & 8.3 & 8.3 & 8.5 & 8.8 & 9.3 & 9.6 & 10.8 & 11.0 & 11.3 \\
\hline
\end{tabular}

Source: GUS (2007-2017). 
expenditure in the cost group referred to as other, described as purchases of goods and services of luxurious nature. increased both in the city and the countryside, thus reflecting the growth of well-being and free decision funds. Both changes indicate a gradual conversion into consumption patterns typical of richer societies.

Assessment of changes in the structure of consumption in the context of convergence processes between the city and the countryside enables the positive verification of the hypothesis concerning the gradual reduction of disparity. Between 2006-2016, inequalities measured by the Kukuła's method decreased (Table 3). Such evidence can be linked to two positive aspects of change in the countryside in the context of a consumption gap decrease. These changes occurred more rapidly than in the city and were more focused (monotonic). As a result. the structure of consumption in the countryside in 2016 changed significantly in comparison to spending ratios in 2006. It can be therefore inferred that rural societies were subject to deeper evolution during the period of European integration. gradually reducing the distance in relation to their urban counterparts.
Deeper disparities in spatial layout are to be expected in less economically developed regions. The results of own research carried out in the Subcarpathian Province confirm that assumption, indicating the differences in economic characteristics describing the inhabitants of cities and villages (Fig. 1).

Some optimism can be observed in the subjective assessment of well-being and directions of its change, both among urban and rural residents. Out of the respondents who described typical situations for their households during the previous year, the majority reported prosperous living and housing improvement. Rural respondents were more prone to assess the situation of their own households as prosperous. Additionally, it was mostly rural dwellers. who experienced a positive change regarding housing improvement. Such tendencies lead to the conclusion that the spatial disproportion in the level of well-being may be decreasing in the region of Subcarpathia.

Also, the differences in the directions of change in income distribution were observed. Regardless of place of residence, the surveyed claimed that their propensity to save is increasing - that declaration is supported by statements regarding an increase in the

Table 3. Measures of changes and spatial diversity of the structure of expenditure on consumer goods and services of urban and rural households in Poland in 2006-2016

\begin{tabular}{|c|c|c|c|c|c|c|c|c|c|c|c|}
\hline Item & 2006 & 2007 & 2008 & 2009 & 2010 & 2011 & 2012 & 2013 & 2014 & 2015 & 2016 \\
\hline \multicolumn{12}{|c|}{ Diversity of the consumption expenditure structure in comparison to the previous year measured by Kukuła's method } \\
\hline Urban & - & 0.0146 & 0.0114 & 0.0123 & 0.0062 & 0.0028 & 0.0067 & 0.0225 & 0.0172 & 0.0077 & 0.0052 \\
\hline Rural & - & 0.0150 & 0.0200 & 0.0118 & 0.0083 & 0.0086 & 0.0144 & 0.0170 & 0.0154 & 0.0088 & 0.0100 \\
\hline \multicolumn{12}{|c|}{ Diversity of the consumption expenditure structure in comparison to the base year (2006) measured by Kukuła's method } \\
\hline Urban & - & 0.0146 & 0.0225 & 0.0192 & 0.0199 & 0.0215 & 0.0238 & 0.0336 & 0.0367 & 0.0390 & 0.0387 \\
\hline Rural & - & 0.0150 & 0.0226 & 0.0292 & 0.0339 & 0.0393 & 0.0402 & 0.0450 & 0.0471 & 0.0511 & 0.0535 \\
\hline \multicolumn{12}{|c|}{ Diversity of the consumption expenditure structure between the city and the countryside measured by Kukuła's method } \\
\hline $\begin{array}{l}\text { Urban- } \\
\text {-rural }\end{array}$ & 0.0798 & 0.0771 & 0.0664 & 0.0675 & 0.0699 & 0.0638 & 0.0663 & 0.0592 & 0.0635 & 0.0631 & 0.0597 \\
\hline \multirow{2}{*}{\multicolumn{4}{|c|}{$\begin{array}{l}\text { Average rate of changes in the } \\
\text { structure of consumption expenditure } \\
\text { between } 2006-2016\end{array}$}} & urban & 0.0107 & \multirow{2}{*}{\multicolumn{4}{|c|}{$\begin{array}{l}\text { Monotonicity of changes in the } \\
\text { structure of consumption expenditure } \\
\text { between 2006-2016 }\end{array}$}} & urban & 0.3628 \\
\hline & & & & rural & 0.0129 & & & & & rural & 0.4136 \\
\hline
\end{tabular}

Source: GUS (2007-2017). 


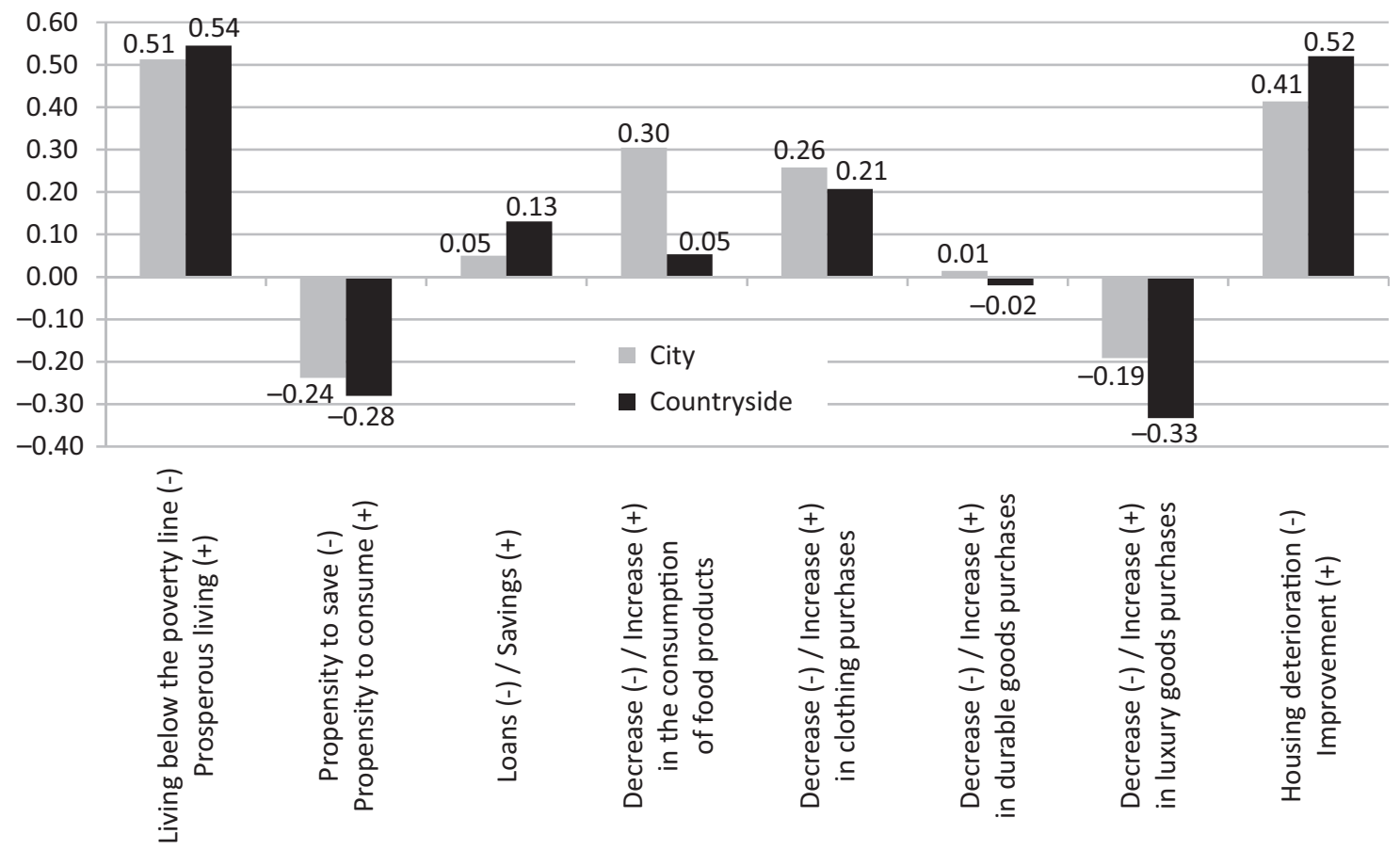

The values were assumed as an average of the indications of respondents based on a scale from -3 to 3 , where 0 - I have no opinion 3 - I agree entirely.

Figure 1. Characteristics of the material situation of Subcarpathian households

Source: calculations based on own research.

level of savings. Such patterns. however. were mostly typical of the countryside, which suggests the existence of different behaviour patterns associated with the forethought of countryside residents.

A more consumption-oriented lifestyle of city dwellers was also indicated by an increase in purchases in most product groups: food; clothing; durable goods and less restraint in purchases of luxury goods than among countryside residents. Similar trends also characterised rural households. However, the increase in purchases involved clothing and food exclusively and its scale was much lower than in the city. Regarding durable goods and luxury goods. rural inhabitants declared a reduction in expenditure.

The results of the conducted research in the Subcarpathian Province led to a favourable assessment of the household situation and an increase of respondent prudence, who try to make savings by limiting purchases not involving basic needs. Such behaviour is mostly typical of persons inhabiting rural areas. Thus. our research findings are in line with other studies generally suggesting a convergence between rural and urban areas. however. the model of income and consumption behaviour of the rural population seems to differ from commonly expected consumptionism. Nevertheless, such inconsistences may be influenced by a diversified inner structure of rural residents' features and behaviour as pointed out by Piekut (2017).

\section{CONCLUSIONS}

The conducted research allows to confirm the initial assumption of numerous overlapping socio-economic problems in the countryside and the existence of adverse disproportions in the development of the Polish countryside in comparison with urban areas. What is more. the transformation observed between 2006-2016 does not allow us to draw the definite conclusion of disproportion minimisation. On the one hand. there are some reasons to believe in a convergence of level of income and expenditure in spatial 
layout. Additionally. a gradual decrease in the disparity in the consumption structure can be observed. On the other hand, labour market indicators for the countryside are not favourable. Also, what is different are the behaviour patterns declared by the inhabitants of the city and the countryside especially in a poorly developed region such as the Subcarpathian Province. A more optimistic assessment of the well-being of rural residents coexists with an increase in the level of thrift. while the attitudes of urban respondents indicate an increase in consumptionism. The presented study results regarding the assessment of well-being on a regional level and their disparity along the citycountryside system suggest the validity of intensifying the analysis of factors differentiating the attitudes and patterns of consumption including this relatively inadequately researched plane of comparison.

\section{REFERENCES}

1. Barigozzi, M., Alessi, L., Capasso, M., Fagiolo, G. (2012). The distribution of household consumptionexpenditure budget shares. Structural Change and Economic Dynamics, 23, pp. 69-91. DOI 10.1016/ j.strueco.2011.09.003

2. Carey, M., O’Donoghue, C., Loughrey, J., Meredith, D. (2014). Rural and urban household consumption behaviour in Ireland. In: O'Donoghue, C., Conneely, R., Frost, D., Heanue, K., Leonard, B., Meredith, D. (eds.) Rural Economic Development in Ireland. The Irish Agriculture and Development Authority, Teagasc.

3. Chmieliński, P., Chmielewska, B. (2015). Social changes in rural areas: incomes and expenditures of rural households. Economics of Agriculture, 4, pp. 907-920.

4. Gîdiu, V., Toader, V. (2011). Analysis of economic gaps between urban and rural Romanian areas. Annals of the University of Oradea, Economic Science Series, 20 (1), pp. 186-192.

5. GUS (2007-2017). Budżety gospodarstw domowych w latach 2006-2016. Dział Wydawnictw Statystycznych GUS, Warszawa.

6. Kukuła, K. (1996). Statystyczne metody analizy struktur ekonomicznych. Wydawnictwo Edukacyjne, Kraków.

7. Leśniak-Moczuk, K. (2008). Dywersyfikacja wewnętrznej struktury dochodów ludności wsi i miast $\mathrm{w}$ kierunku spójności pomiędzy środowiskami. Nierówności Społeczne a Wzrost Gospodarczy, 12, pp. 279-295.

8. Piekut, M. (2017). Wzorce konsumpcji według typów wiejskich gospodarstw domowych w latach 2004-2014 [Consumption patterns by types of rural households in 2004-2014.]. Difin, Warszawa.

9. Rivera, M., Knickel, K., de los Rios, I., Ashkenazy, A., Pears, D.Q., Chebach, T., Sumane, S. (2018). Rethinking the connections between agricultural change and rural prosperity: A discussion of insights derived from case studies in seven countries. Journal of Rural Studies, 59, pp. 242-251. DOI 10.1016/j.jrurstud.2017.07.006

10. Simler, K., Dudwick, N. (n.d.). Urbanization and Rural-Urban Welfare Inequalities. PRMPR Report. World Bank Group. Retrieved from: http://siteresources. worldbank.org/INTPOVERTY/Resources/060310_ Simler_Dudwick_Rural-Urban_Welfare_Inequalities. pdf [Accessed 16.05.2018].

11. Utzig, M. (2017). Sustainable consumption of rural and urban households in Poland. Acta Scientiarum Polonorum Oeconomia, 16 (2), pp. 135-144. DOI: 10.22630/ ASPE.2017.16.2.26 